\title{
長大吊橋のハンガーロープピン定着部補強構造 の力の伝達機構と疲労挙動
}

\author{
大橋治一 ${ }^{1} \cdot$ 藤井裕司 $^{2} \cdot$ 小野秀一 ${ }^{3} \cdot$ 三木千壽 4 \\ ${ }^{1}$ 正会員 工莜 本州四国連絡橋公団 設計部設計第二棵 (テ 105 東京都港区虎ノ門 5-1-5) \\ ${ }^{2}$ 正会員 工悠 本州四国連絡橋公団 第二管理局坂出管理事務所 (广 762 香川県坂出市川津町下川津 4388-1)

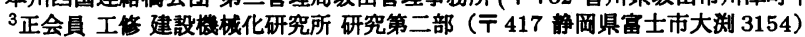 \\ ${ }^{4}$ 正会員 工博 東京工業大学教授 工学部土木工学科 (广 152 東京都目黒区大岡山 2-12-1)
}

\begin{abstract}
吊橋のハンガーロープと補剛桁連結部をピンで結合したピン定着部では，補剛妳からのカはピンとピン孔の 支圧によりハンガーロープへと伝達される. 暴風時などでは主ケーブルと補䣓析に相対な㚆位が生じるためハン ガーロープのピン定着部には面外の力が作用する. このとき定着ピンは片当たりの状態となることや，絽り返 しの力が定着構造に作用するとなどが予想されるが、このような場合の応力挙動や疲労举動は明確でない，そ こで本論文は, 補岡トラスを有する長大吊㛢で採用が検討された二種類の定着構造についての静的載荷試験と 疲労武験を実施し，構造上の弱点部の把暒，疲労強度と疲労挙動の確認を行った結果を報告する.
\end{abstract}

Key Words : pin connection, suspension bridges, fatigue strength, stress distribution

1.はじめに

本州四国連絡橋の吊橋のハンガーロープには従来，ス トランドロープの一種である CFRC(Center Fit Rope Core) を用い，これをケーブルバンドに鞍掛けし，端部 のソケットを補剛析の定着構造にはめ込み, 支压によ り荷重を伝達する形式が用いられてきた．明石海峡大 橋ではこれに替えて，ハンガーロープにポリエチレン 管で被覆処理したセミパラレルケーブルを用いて，両 端のソケットをピンでケーブルバンドと補剛析の双方 に連結する形式が採用されている。この方法は，ハン ガーロープの鞍掛けがないためにハンガーの二次曲げ 応力が軽減されること，ピンによる定着構造は従来の ソケットの支压伝達による方法と比へて構造が簡素と なること, 被覆処理されたセミパラレルケーブルを用 いることで長尺化するハンガーロープのプレハブ化と メンテナンスフリーが可能となること, などの利点が ある.

補剛トラスを有する長大吊橋においては，暴風時に 生じる主ケーブルと補剛析の相対変位により，ハンガー には大きな角折れが発生する. このため明石海峡大橋 の特に大きな角折れが生じる支間中央付近および側径 間端部付近の角折れが 4.5 7.5 度の範囲では，面外に も回転可能なユニバーサルピンを, 7.5 度以上の角折れ の管用では従来通りの CFRC の鞍掛けを採用している. 橋軸直角方向の角折れが比較的小さい(最大 4.5 度) 主 塔付近の定着部では, 橋軸方向のみに回転可能な一方 向ピンを採用している.
わが国でのピン定着構造の事例は, 中小吊橋に多い. 一般にピン定着構造は，ピンの支压応力度とピン孔部 の補強から，溶接による重ね板構造とされる. ハンガー からの荷重は，定着ピンを介して，これら重ね板で分担 し，重ね板間の溶接により主構造へと伝達される. しか し, 定着ピンの支圧応力の均等性や, 暴風時のように ピンが片当たり状態で力を受ける場合の応力挙動が明 らかではなく，このピン定着構造が明石海峡大橋のよ うな大規模構造物に本格的に採用されることから，ピ ン定着構造の構造上の弱点部之力の伝達機構を把挃す る必要がある.

本論文では, 応力状態の厳しい一方向ピンの定着部 を対象とした実物大の試験体を製作し，ピン定着構造 のピン孔周辺部の定着板と補強板の応力状態, ピンと ピン孔の接触状態，およびピンの曲げ応力の測定，さ らに暴風時の状態での度労試験を実施した結果を報告 する.

\section{2. 試験体}

明石海峡大橋で採用されるピン定着構造は, 補剛卜 ラス上弦材ウェブを鉛直上方に延長した定着板にピン 孔を設け，その断面欠損分を補強する 2 枚の補強板を 両面に溶接で取り付けた構造である. また，暴風時な どには定着部に面外力が作用するため，ピン孔の両側 に補強リブを取り付けている，定着板と 2 枚の補強板 により構成される定着部の厚さは, ピンとピン孔の許 

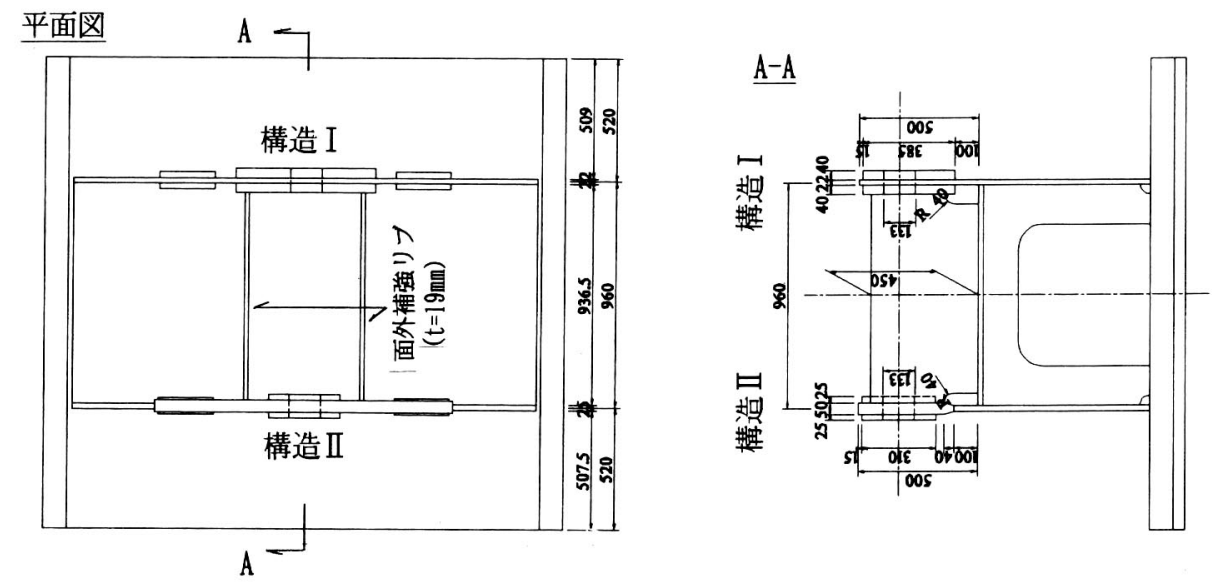

構造 I 側面図

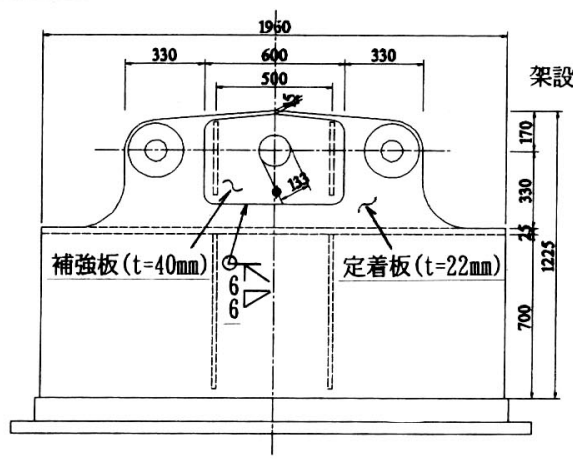

構造 II 側面図

図-1 試験体の形状と寸法

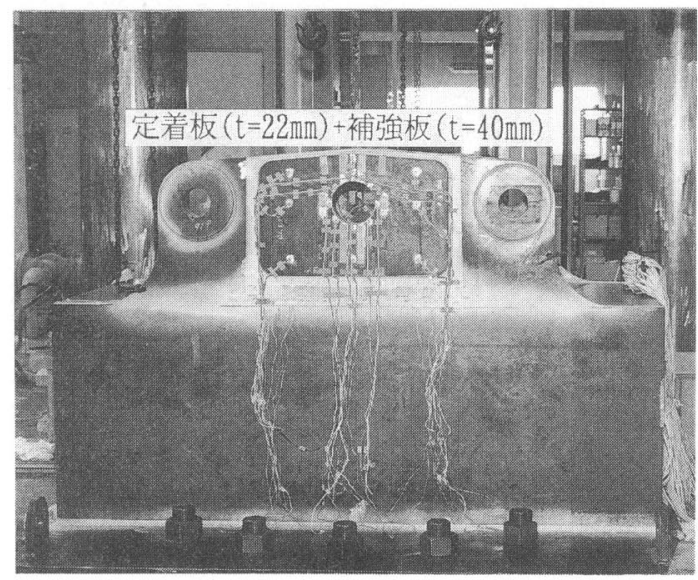

図-2 構造 I

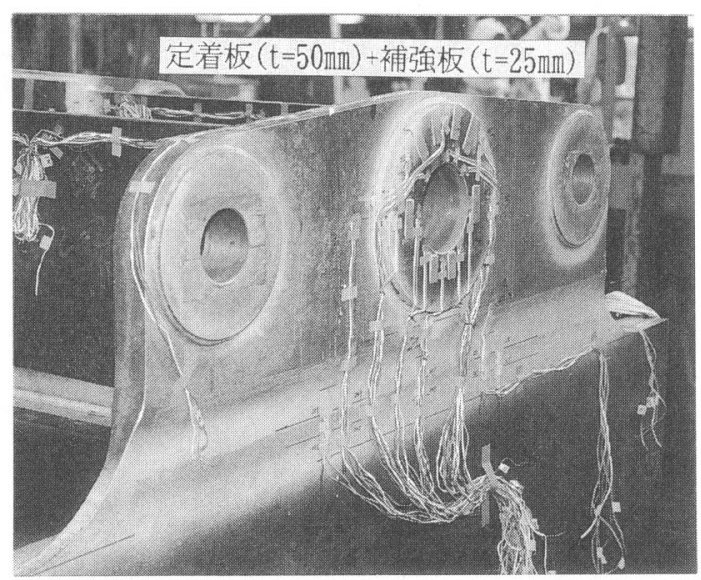

图-3 構造 II
容支压応力から $100 \mathrm{~mm}$ としている.

本試験では, トラス上弦材の 2 枚のウェブに, 定着板 と補強板の板厚構成と定着部補強板の形状が異なる二 種類の定着構造を試験の対象とした.ここでは二種類 の構造をそれぞれ構造 I, 構造 II と称することとする.
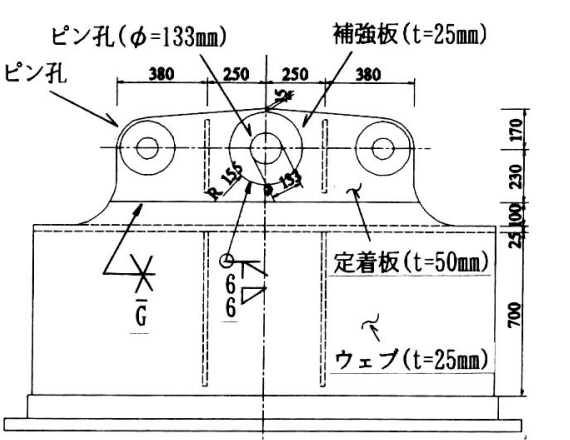

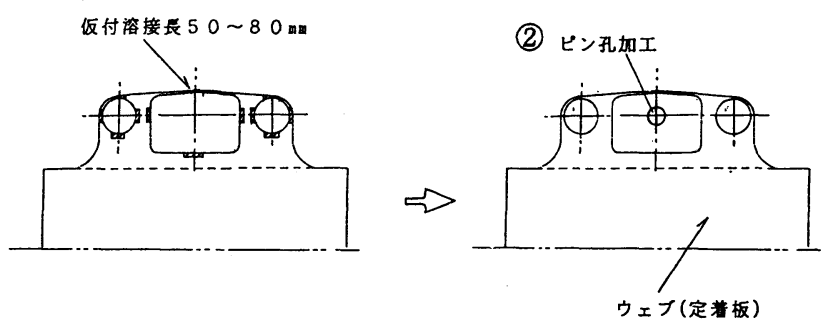

(3) 補強板外周本溶接（手溶接）

構造 II

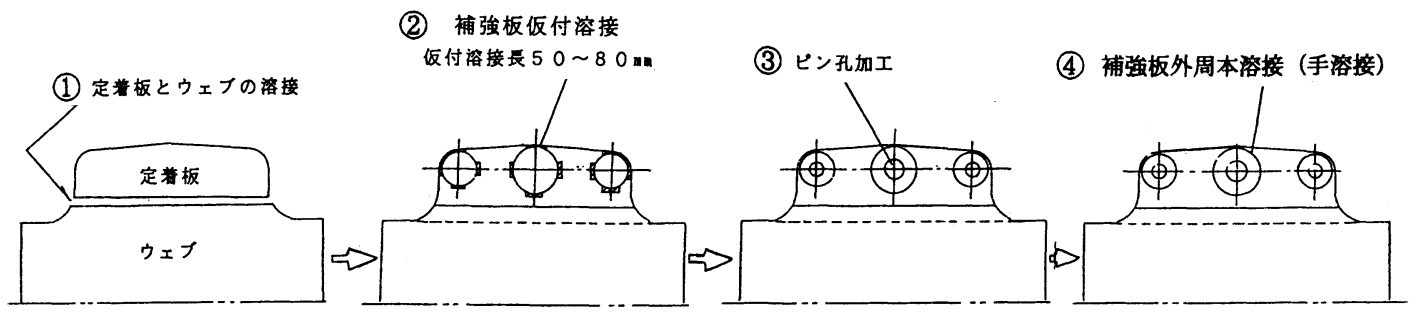

図-4 ピン定着部の組立順序

表-1 使用釾材の機械的性質と化学成分 (ミルシートより)

\begin{tabular}{|c|c|c|c|c|c|c|c|c|c|c|c|c|c|c|c|c|c|}
\hline \multirow{3}{*}{ 部材名 } & \multirow{3}{*}{ 材質 } & \multicolumn{4}{|c|}{ 機械的性質 } & \multicolumn{12}{|c|}{ 化学成分 } \\
\hline & & \multirow{2}{*}{$\begin{array}{l}\text { 降伏点 } \\
\left(\mathrm{N} / \mathrm{mm}^{2}\right)\end{array}$} & \multirow{2}{*}{$\begin{array}{c}\text { 引張強さ } \\
\left(\mathrm{N} / \mathrm{mm}^{2}\right) \\
\end{array}$} & \multirow{2}{*}{$\begin{array}{l}\text { 伸び } \\
\text { (\%) }\end{array}$} & \multirow{2}{*}{$\begin{array}{c}\text { 皎り } \\
(\%)\end{array}$} & C & $\mathrm{Si}$ & $\mathrm{Mn}$ & $P$ & $S$ & $\mathrm{Cu}$ & $\mathrm{Ni}$ & $\mathrm{Cr}$ & Mo & $\mathrm{Nb}$ & $\mathrm{V}$ & Ceq \\
\hline & & & & & & \multicolumn{3}{|c|}{$\times 100$} & \multicolumn{2}{|c|}{$\times 1000$} & $\times 100$ & \multicolumn{2}{|c|}{$\times 10000$} & \multicolumn{4}{|c|}{$\times 100$} \\
\hline 定着ピン & SCM435 & 922 & 1.020 & 18 & 58 & 35 & 25 & 78 & 16 & 18 & 17 & 8 & 111 & 16 & & & \\
\hline ウェブ材(1) & SM490A & 418 & 561 & 25 & & 17 & 46 & 134 & 20 & 5 & 1 & & & & 2 & & 41 \\
\hline 補強板 & SM490A & 383 & 531 & 32 & & 17 & 44 & 134 & 16 & 4 & 1 & & & & 2 & & 41 \\
\hline ウェブ材(2) & SM490YB & 380 & 553 & 29 & & 17 & 47 & 144 & 10 & 2 & 1 & & & & 3 & 6 & 43 \\
\hline 定着板(2) & SM $490 \mathrm{~A}$ & 396 & 534 & 29 & & 13 & 27 & 137 & 18 & 5 & 1 & & & & & 21 & 37 \\
\hline
\end{tabular}

力が作用したときの定着部の曲げ剛性を增すために大 きな五角形状とし，面外の補強リブが補強板に取り付 くようにした．また，この構造は定着部の鎆重を軽減 するには有効であるが，薄い定着板に厚い補強板を取 り付けるため構造上検討が必要である。

構造 II (図-3 参照) では, 弦材ウェブ (板厚 $\mathrm{t}=25 \mathrm{~mm}$ ) を上フランジ直上で $\mathrm{t}=50 \mathrm{~mm}$ の板厚に增厚した定着板 に, 板厚 $\mathrm{t}=25 \mathrm{~mm}$ の円形状の補強板を取り付けた．補 強板の形状を円形にすることは，他の形状に比へ幾何 学的にも安定し，円孔を補強する方法としては一般的 とされている. またこの構造は, ウェブの板継き溶接が 必要なため, その部分の溶接品質の確保が重要である.

補強板の溶接は, 構造 I, II とも補強板侧に $6 \mathrm{~mm}$ の 開先を取る部分溶込みグルーブ溶接と脚長 $6 \mathrm{~mm}$ のすみ 肉溶接を併用した溶接としている。，一般に，このよう な重ね板の溶接はすみ肉溶接によって行われる，道路 橋示方書 $^{1}$ によると，すみ肉溶接のサイズ $\mathrm{S}$ は溶接部 材の厚い方の板厚を $\mathrm{t}$ とすると $\mathrm{S} \geq \sqrt{2 \cdot t}$ を標準とするこ ととしている. 本試験体の場合は板厚が $50 \mathrm{~mm}$ である
ので $\mathrm{S}=10 \mathrm{~mm}$ が必要となる．しかし，本試験体の溶接 は荷重を伝達する重要な溶接であることから，溶接の 精度やのど厚の碓保，確実な溶込みを考虑して，この ような併用型の溶接方法とした。

ピン孔の加工と補強板の組立手順を図-4に示す．補 強板は補強板の外縁部で定着板に仮付け溶接し，ピン 孔を所定の径で切削した後, 外縁の全周を溶接してい る. またピン孔内面の定着板と補強板の溶接はしてい ない.

試験には，実橋で使用されるハンガーロープと同等 なロープと， $\phi 130 \mathrm{~mm}$ の定着ピンを使用した。

主要な使用鋼材の機械的性質と化学成分を表-1 に 示す.

\section{3. 試験方法}

試験には静的に $5900 \mathrm{kN}$ ，動的に $3900 \mathrm{kN}$ の載荷能力 を有する大型疲労試験機を用いた。

載荷の要領を図-5に示す．載荷は常時を想定した荷 

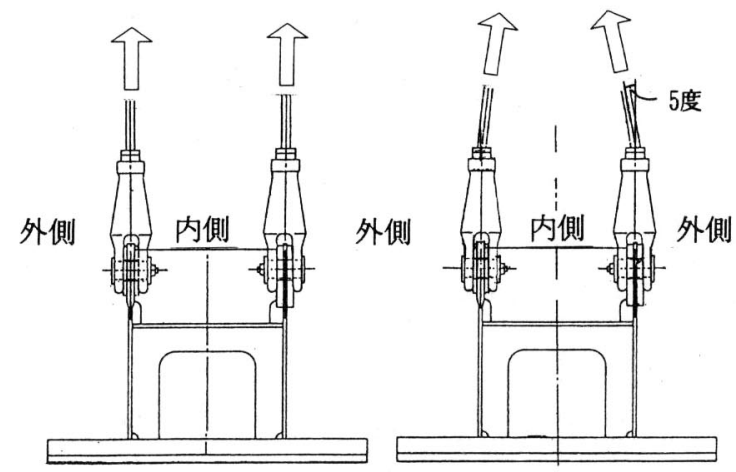

図-5 載荷の要領

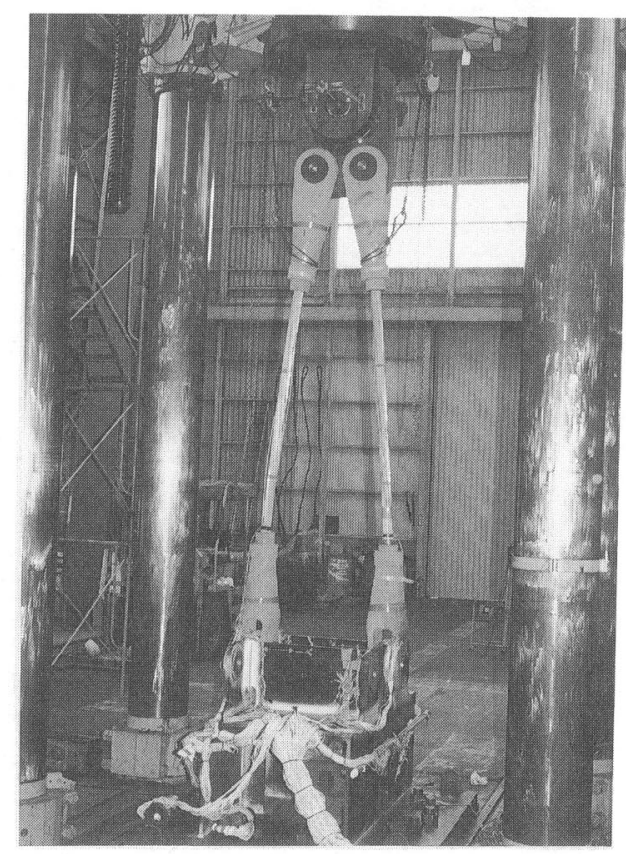

图-6 載荷状況

重状態と暴風時を想定した場合の 2 ケースとした. 常 時を想定した載荷は, 二本のハンガーロープを平行に 取り付けて, 定着部には鉛直方向の荷重を作用させた. また, 暴風時を想定した載荷は, ハンガーロープと定着 板の相対的な角折れが 5 度となるようにハンガーロー プを取り付けて, ピン定着部には面外方向の荷重を作 用させた (図-6 を参照).

疲労試験は定着部に面外荷重が作用する暴風時を想 定した載荷状態で行った．また，痩労試験を実施する 前に, 常時と暴風時を想定したそれぞれの載荷状態で 静的な載荷試験を行った. さらに疲労試験後には, 疲
労試験中に検出されたきれつの破面調查を実施した.

\section{4. 静的載荷試験}

\section{(1) 試験計画}

ハンガー張力による荷重は, ピンとピン孔との支圧 により定着構造に伝達され, 定着部の設計では八ンガー からの荷重は, 定着板と 2 枚の補強板に均等に伝達さ れるとしている. しかし, 実際にはピンとピン孔の接 触状㦔や荷重の載荷状態, つまり暴風時に生じるピン の傾斜による片当たりや, ピン孔内面のピンとの接触 部の凹凸などにより, 定着部に作用する荷重状態は, 設 計で仮定している場合より簃しい状態となることが考 えられる. また, ピンとピン孔は径が異なるために，こ れらの接触部では高い支圧応力が生じると予想される.

そこで, 静的載荷試験ではピン定着部の応力状態を 測定するとともに，応力の発生に影響を及ぼすと考え られるピンとピン孔内面の接触状態, および定着ピン の応力を測定した.

静的載荷試験は常時と暴風時を想定したそれぞれの 状態で実施した．載荷荷重は一本のハンガーロープあ たり $980 \mathrm{kN}$ (二本で $1960 \mathrm{kN}$ ) とした. 荷重の設定は, 実橋のハンガー張力が最大約 $1470 \mathrm{kN}$ と想定されてい るが, 試験体の材質が材料手配の都合から SS400 材を 使用している筒所があり, 実橋の SM490Y 材とは異な るため, 本試験では最大 $980 \mathrm{kN}$ とした。

静的載荷試験での着目点は以下の通りである.

\section{a) ピンとピン孔内面の接触状態}

ピンとピン孔の接触状態は, 力が定着板と補強板に 伝達される機構に影響を及ぼすと考えられる．そのた め, 所定の荷重を載荷したときのピンとピン孔内面の 接触状態を調查した.

接触状態の調查には感圧フィルムを用いた．この感 圧フィルムは厚さ $0.2 \mathrm{~mm}$ で面压 $20 \mathrm{MPa}$ 以上で変色す るタイプである. 剆定方法は, 載荷前にあらかじめピ ンとピン孔の隙間に感圧フィルムを㨂入しておき, 荷 重の載荷, 除荷後に取り出し, 感圧フィルムの変色状 態から接触面の形状を測定した.

\section{b) 定着部の応力測定}

定着部の応力は, ピンとピン孔の接触状態または荷 重の載荷状態によって異なる。 そこで, 定着部に作用 する応力状態を把握するために, 供試体の各部にひず みゲージを貼付して応力測定を行った．応力の測定位 置は, ピン孔周辺部, 補強板外周の溶接部, 定着板下 部の主構弦材上フランジとの交差部を主とし, 暴風時 載荷時には定着部に面外曲げが作用すると考えられる ので, すべて定着部の表裏の位置で応力測定を行った. また, 応力測定では主応力の大きさと方向を明らかに 

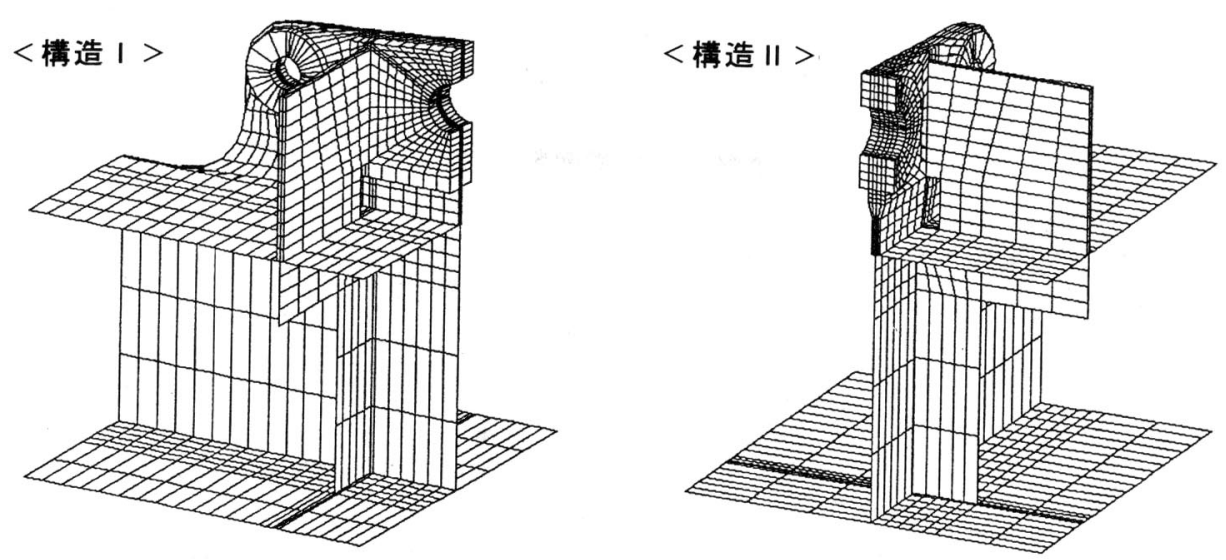

図-7 3 次元モテル要素分割図

するため，主に三軸タイプのひずみゲージを用いた.

\section{c) ピンの応力測定}

ピンは補剛トラスからの荷重をハンガーに伝達する 重要な部材であり, ピン孔と接するピンの表面には高 い支圧応力が作用し，ピンの軸方向には曲げ応力が発 生する. ピンの曲げ応力は, ピンと定着部の接触状態 およびハンガーケーブルのソケットによるピンの支持 状態の影響を受けるが，その状況は必ずしも明らかで はない.

そこで, 定着ピンの上下面でピン軸方向の応力測定 を行い, ピンの曲げ状況を調查した. ピンは直接にピ ン孔と接するため，ピンの円周方向に幅 $10 \mathrm{~mm}$ ，深さ $2 \mathrm{~mm}$ のゲージ保護用の溝を設け, その溝底での応力測 定とした. ピン軸方向の応力測定位置は，それぞれが 定着板と二枚の補強板の板厚内に配置する関係上, 3 箇所とした.

\section{(2) FEM 構造解析結果}

実験に先立って, 検討すべき問題点を明確にし, 概 略の定着構造の応力挙動を把握するため, FEM により 試験体の構造解析を行った. ここでは解析の概略と主 な結果について述べる.

解析モテルは，構造 I と構造 II をそれぞれ $1 / 2$ とし た $1 / 4$ モデルとした. 要素分割は，定着部では溶接部 の影響を考慮するために 3 次元固体要素とし, 面外補 強板も 3 次元固体要素, そのほかは 3 次元シェル要素 とした. 定着板と補強板の溶接は, 補強板最外縁部の 要素を定着板と結合させてモデル化した. 図-7に 3 次 元モデルの要素分割図を示す.

荷重は常時載荷時では鉊直方向に $1470 \mathrm{kN}$ の力を載 荷した. 暴風時の場合は 5 度斜め方向に $1470 \mathrm{kN}$ を載荷 したときの分力として, 鉛直方向に $1460 \mathrm{kN}$, 水平方向
に $127 \mathrm{kN}$ の力を載荷した. また，ピンの傾斜によるト ルクを, 水平力がソケット上端に作用したときのモー メントとして $120 \mathrm{kN} \cdot \mathrm{m}$ をピン中心に作用させた. 鉛直 方向の支圧力はピン孔内面の要素の表面に圧力荷重と して入力し，モーメント荷重は等価な偶力に置換した 節点荷重とし，水平力も節点荷重として入力した． い ずれの荷重もピン孔の周方向については, 中心角が 80 度となる範囲に $\cos$ 分布させた. 主な解析結果を以下 に述べる. ただし，ここで示す応力值はVon Mises の 相当応力である.

\section{a) 常時載荷時 FEM 結果}

構造 I, II の応力分布状態は, どちらの構造もピン 孔上部で $160 \mathrm{MPa}$ を越える応力となり, ピンとの接触 部近傍では $200 \mathrm{MPa}$ 程度となっている. 弦材上フラン ジと交差する付近の定着板の応力は, 板厚の薄い構造 I の方が若干高い応力となっている. 補強板外周の溶 接部には大きな応力は生じていない。これら結果より, 常時載荷時においては構造上どちらにも特に問題とな る笛所はなかった。

\section{b) 暴風時載荷時 FEM 解析結果}

構造 I, II のどちらの構造も補強板外周の溶接部に 沿って高い応力（約 $160 \mathrm{MPa}$ ）が発生する. また構造 I では, 構造 II に比べ高い応力の範囲が溶接部近傍のご く狭い範囲となっており, 板厚構成之面外補強リブに よる面外方向の剛性の違いによる応力集中が現れてい るものと考えられる.

ピン孔のピンとの接触部付近の応力は, どちらも高 い応力となり, 特にピン孔エッジ部では極めて高い応 力が発生している. また, 構造 II では定着部の面外補 強リブが補強板の外側に位置しているため，ピンの接 触部に作用した面外方向の力は, 一旦定着板に全部流 れたのち補強リブに伝達される. このため補強板に直 


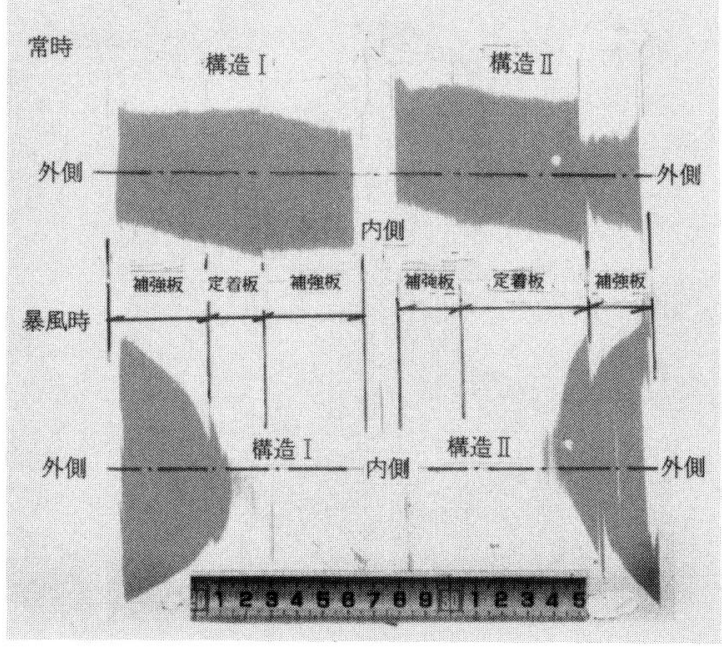

图-8 ピンとピン孔の接触状况

接補強リブが取り付けられている構造 I に比べると接 触部に発生する応力が高くなっている.

暴風時の応力分布状況から判断して, 常時載荷時に 比へ応力状態が綮く, 特にピンの片当たりによって, ピ ン孔上部のピンとの接触部および補強板外周の溶接部 に高い応力が発生することが判明した。

\section{(3) 試験結果}

a) ピンとピン孔の接触状態

荷重を $980 \mathrm{kN}$ まで載荷したときのピンとピン孔の接 触状態を図-8 に示す. 着色部分が接触している範囲で ある.

常時を想定した載荷時のピンとピン孔の接触状態で は, ピンは定着板には均等に接しているが, 補強板に は僅かしか接触していない場合がある．また補強板に 接していても全体的には補強板より定着板の方が接触 している幅が大きい，これはピン孔内面の定着板と補 強板の段差の影響によるものである.この段差は補強 板の外周を溶接したときに生じる残留応力により, 補 強板がピン孔の直径方向に変形して生じたものと考え られる. 段差の高さを測定した結果, 定着板が補強板 より最大で $0.2 \mathrm{~mm}$ 程度凸となっていた. また，その大 きさは構造 I の方が構造 II より小さかった.これは, 構造 I の方が補強板が厚く大きいことから, 溶接の残 留応力による補強板の変形が小さかったためと考えら れる.

暴風時を想定した載荷では，ピンが完全に片当たり の状態となり, 構造 I, II のいずれの試験体の場合も 内側の補強板には接していない状況であった，構造 I は構造 II より補強板が厚いため, 外側の補強板が受け る荷重の割合が構造 I の方が大きいことを示している.
つまり, 構造 I ではピンからの荷重のほとんどが, 外 側の補強板から補強板外周の溶接部により主構造へ伝 達されることとなっている.

ピンとピン孔の接触理論のヘルツの公式 (Hertz's Formula） 1)2) では, a) 接触面積の大きさが曲率半径に比 べて十分小さいこと, b) 接触部の応力が弾性限度内で あり組織的に均一であること，という仮定条件から導 かれたものである. ヘルツ理論の適用性について道路 橋示方書では, ピン孔径 $\mathbf{r}_{1}$ とピン径 $r_{2}$ の比率 $\left(\mathbf{r}_{1} / \mathbf{r}_{2}\right)$ が 1.02 より大きい場合にへルツの公式を適用するよう に規定されている. 今回の試験では, $\mathrm{r}_{1} / \mathrm{r}_{2}$ が 1.023 と なっている. そこで, 本試験で得られたピンとピン孔 の接触状態とこの公式から求められる值を比較してみ た. ただし, ヘルツの公式ではピンの軸方向の応力分 布は一定としていることから, この検討には常時載荷 時のみを対象とした.

表-2 に実測されたピンの接触状態と公式から求めら れた値の比較を示す. 接触面積はプラニメータを用い て測定した. 接触幅は接触面積をピン軸方向の接触長 さで割って求めた平均值である. 参考までに暴風時載 荷時の接触面積と接触幅についても示すが, この時の 接触幅はピン孔外縁部の最大接触幅を示す.

常時載荷による接触幅の実測値は, ヘルツの公式か ら求められた接触幅より大きい值となっている．この 原因として，a) ヘルツの公式により求められた值には プレスケールの厚みが考慮されていないこと，b) 接触 部が局部的に塑性変形をしている可能性があること，c） 接触幅はヘルツの公式からも判断できるようにピン径 とピン孔径の僅かな違いで差がでるため，ピン孔内面 の段差によるばらつきが実測值に含まれること，が考 えられる. b) の接触部の塑性変形については, ヘルツ の公式を用いて接触幅の実測值から最大接触王を推定 すると $\mathrm{P}_{\max }=260 \mathrm{MPa}$ 程度となり，接触部の塑性変形 はないと考えられるが，ピン軸方向に接触状態が均等 でないことから局部的な塑性変形の可能性があるもの と考えた。

暴風時載荷時の接触状態は, 常時載荷時よりピン孔 の周方向には長く接触しているが, 逆にピン軸方向で は短くなっており，接触面積は小さくなっている．この 状態では, 接触面で均等に荷重を受けていたと仮定し ても，接触圧は $350 \mathrm{MPa}$ となり，材料の機械的性質か ら判断して，ピン孔のエッジ部では塑性変形を起こし ていることが考えられる.

また今回の測定は, 荷重 $980 \mathrm{kN}$ までの載荷としたが, 実橋では $1470 \mathrm{kN}$ の荷重が作用するため, 常時の状態 でもピン孔のエッジ部が塑性変形を起こす可能性が大 きくなり, 暴風時ではその範囲はさらに広がるものと 考えられる. 
表-2 ピンとピン孔の接触状帞測定結果

\begin{tabular}{|c|c|c|c|c|c|c|c|}
\hline \multirow{3}{*}{ 名 称 } & \multicolumn{5}{|c|}{ 常時載荷時 } & \multicolumn{2}{|c|}{ 暴風時載荷時 } \\
\hline & \multicolumn{3}{|c|}{ 実測値 } & \multicolumn{2}{|c|}{ ヘルツの公式 } & \multirow[b]{2}{*}{$\begin{array}{c}\text { 接触幅 } \\
(\mathrm{mm})\end{array}$} & \multirow[b]{2}{*}{$\begin{array}{c}\text { 接触面積 } \\
\left(\mathrm{mm}^{2}\right)\end{array}$} \\
\hline & $\begin{array}{c}\text { 接触面積 } \\
\left(\mathrm{mm}^{2}\right)\end{array}$ & $\begin{array}{l}\text { 接触幅 } \\
(\mathrm{mm})\end{array}$ & $\begin{array}{c}\text { 最大接触压 }_{(\mathrm{MPa})} \\
(\mathrm{MPa)}\end{array}$ & $\begin{array}{c}\text { 接触幅 } \\
(\mathrm{mm})\end{array}$ & $\begin{array}{l}\text { 最大接触圧 } \\
\text { (MPa) }\end{array}$ & & \\
\hline 構造 I & 4,960 & 52 & \multirow{2}{*}{260} & \multirow{2}{*}{36.6} & \multirow{2}{*}{355} & 103 & 3,010 \\
\hline 構造 II & 4,710 & 49 & & & & 115 & 2,760 \\
\hline
\end{tabular}

*1）接触幅を $50 \mathrm{~mm}$ （実測值の平均）としてヘルツの公式から算出した值。

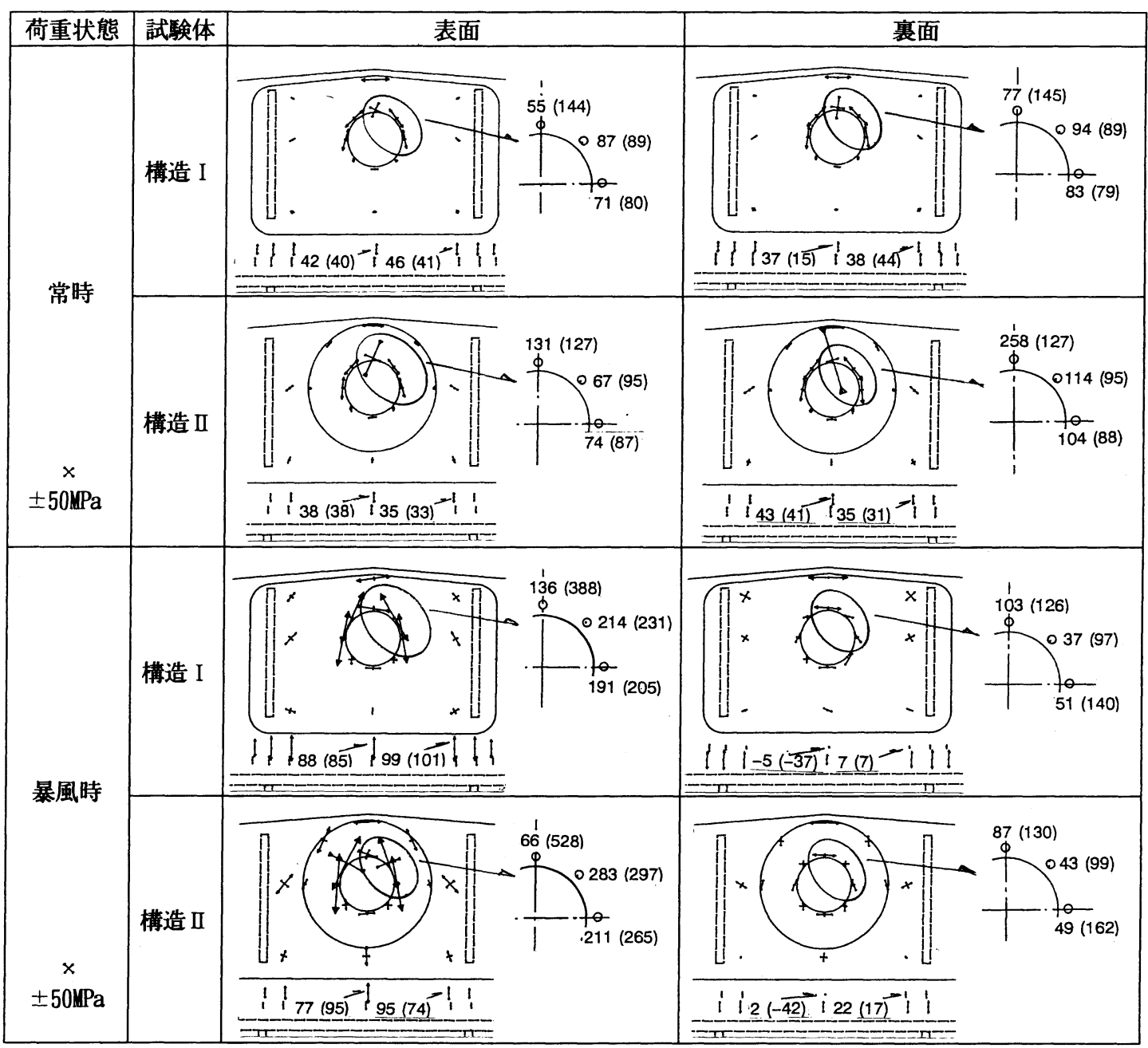

※ 実測値（FEM値）

図-9 定着部の応力測定結果

b）定诣部の応力測定

荷重 $980 \mathrm{kN}$ 時の常時載荷時および暴風時載荷時の主 応力の状態を図-9に示す。ここでは，主な測定位置で の応力実測値と FEM 解析値を記入している. ただしこ
こで示す FEM 解析値は, 応力測定位置に相当する要 素応力に $2 / 3$ を乗じて, 荷重 $980 \mathrm{kN}$ 換算とした. また, 定着板下部では鉛直方向のみの測定としたので，FEM 解析值も鉛直方向の応力を示した。 


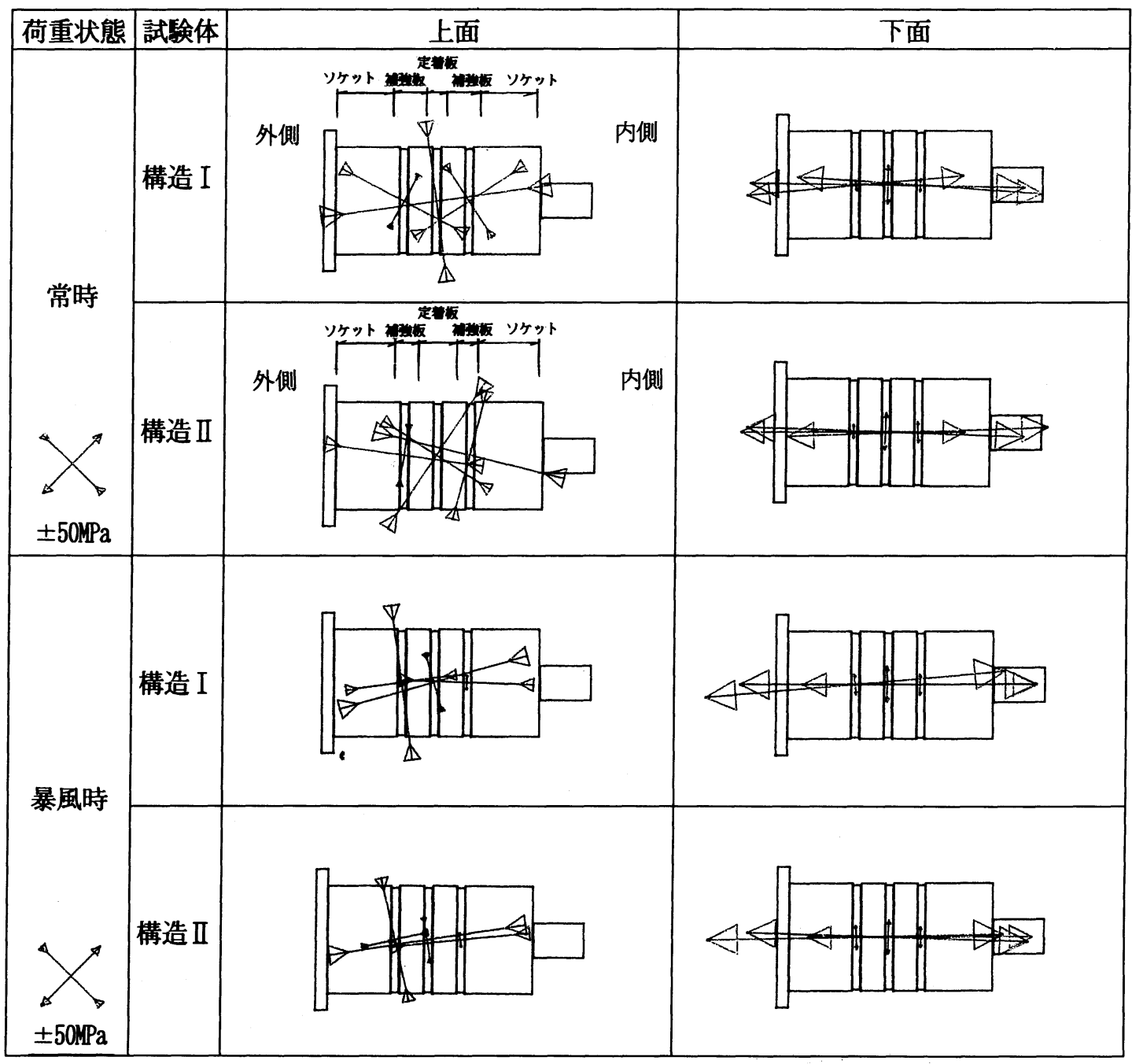

图-10 ピンの応力測定結果

（a）集中荷重（b) 等分布荷重

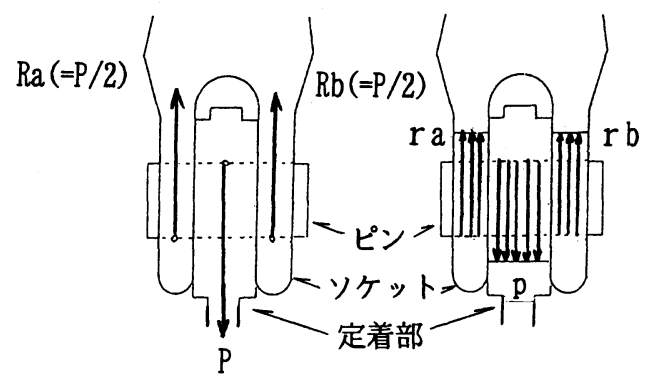

图-11 ピンに作用する外力の状態

直上の接触部で最大約 $80 \mathrm{MPa}$ の圧縮応力が, 構造 II では同様の位置に最大約 $250 \mathrm{MPa}$ の圧縮応力が作用し ている. この構造 I と II の応力の差は, 先に述へたよ うにピン孔内面の定着板亡補強板の段差による接触状 態の違いによるものと考えられる. また, 構造 I と構 造 II で他のピン孔周辺部の応力は, ピン孔の接線方向 に $70 \sim 100 \mathrm{MPa}$ の引張応力か， 補強板上縁部の溶接部 近傍で水平方向に $100 \mathrm{MPa}$ の引張応力が作用している. このように, 直接ピンが接する付近の補強板の応力は, ピンの接触状態により表裏の関係で差が生じているが, それ以外の位置では補強板の応力に特に差はない，そ のほか補強板外周の溶接部近傍や定着板下部で $50 \mathrm{MPa}$ 程度となっている。 
（1）常時

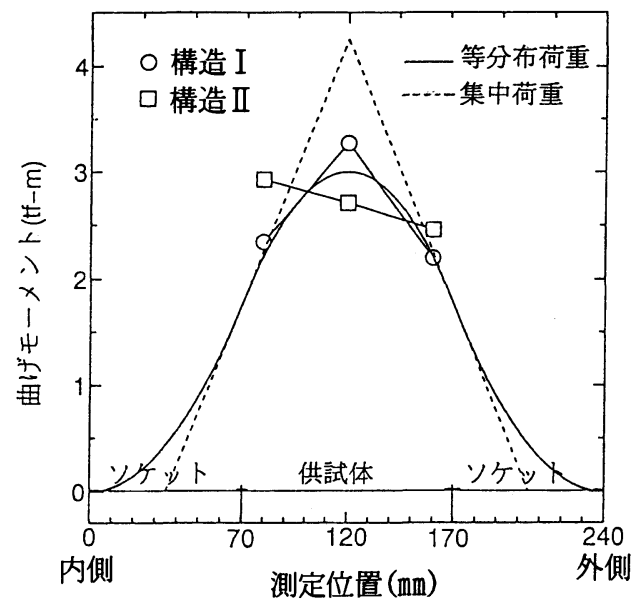

（2）暴風時

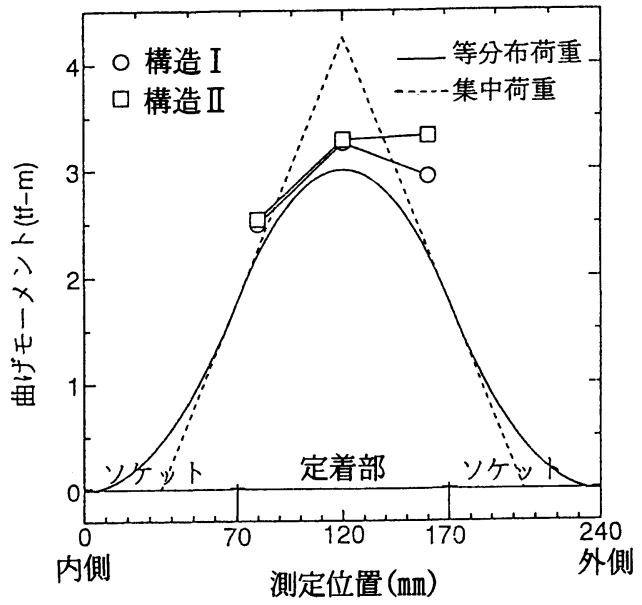

図-12 ピン軸方向のモーメント分布図

触部を除いて，ほほ FEM 解析値と同程度となっている.

暴風時載荷時の測定結果では, 定着部に面外の曲げ が作用し, 定着板の表裏において主応力の大きさと方 向が異なっている. また, ピンの片当たりによって荷 重を直接受ける補強板の応力は, かなり大きな値となっ ており, 特にその補強板のピン孔周辺部では $230 \mathrm{MPa}$ を超える引張応力が発生している. 構造 I と II で応力 の状態を比較すると，構造 I では補強リブが補強板に 取り付けられているため, 補強リブ近傍の定着部の応 力は構造 I の方が小さい值となり, 曲げ成分も小さく なっている. しかし, 補強板下部の定着板と弦材上フラ ンジの交差部では, 構造 I の方が大きな応力になって おり, 曲げ成分も構造 I の方が大きい.これは定着板 の板厚が，構造 I の方が薄いためであると考えられる.

また暴風時載荷によって大きな支圧応力が作用する ピン孔直上縁部では, 塑性変形を起こしていたことが 判明した. これは湘定中にピン孔直上のひずみゲージ が測定限界を超えたことで明らかとなった。このため, 図-9に示す応力湘定結果において, ピン孔上部の応力 が他の部位の応力と比へ小さいのは, ピン孔直上部の ひずみゲージを貼り替えて再湘定を実施したためであ る. また, 図-8で示した暴風時のピンの接触状態で, ピン孔エッジ部でわずかに接触していない範囲がある が,この範囲が特に塑性変形の進んだ範囲であると考 えられる.

補強板外周の溶接部および定着板下部の引張側の応 力は, 構造 I で $100 \mathrm{MPa}$, 構造 II では 70MPa となっ ている. この応力差は先にも述へたとおり, 定着板の 板厚の差によるものと考えられる.

暴風時載荷時の実剆応力と FEM 解析値を比較する
と, ピンが接触する位置では FEM 解析值の方が実測 応力值より大きくなっているが, それ以外のところで はほほ同様な値となっている.

\section{c) 定着ピンの応力}

荷重 $980 \mathrm{kN}$ 載荷時のピンの主応力測定結果を図-10 に示す. ピン上面ではピンの軸方向に压縮応力が, 下 面では軸方向に引張応力が卓越しており, ピンには曲 げが作用している.

そこで, ここではこの実測応力からピンに作用する 外力を推定し, 現行設計法 ${ }^{1) 3)}$ との比較を試みた. まず, 実測応力からピンに作用している曲げモーメントを算 出し, ピン軸方向の曲げモーメント分布を求めた. ピ ンを設計する場合, 外力は図-11(a),(b) に示すように, (a) 外力とピンが受ける力を集中荷重とした場合と, (b) それぞれが等分布としている場合があり，一般に設計 では (a)のように仮定していることが多い.

図-12 に常時載荷時と暴風時載荷時のピンの曲げ応 力から求めた曲げモーメントの分布を示す. 常時載荷時 の場合, ピンとピン孔の接触状態は, 構造 I と構造 II とでは異なっているため, 実測值から求めた曲げモー メントの分布は両者で異なっている. しかし，この状 態は両者ともに外力を等分布で仮定した場合に近い。

暴風時載荷時の場合, 構造 I, 構造 II とも実測値か ら求めた曲げモーメントは，ほほ同じ分布である. 常 時載荷時に比べて曲げモーメントの分布に差がないの は, ピンの片当たりにより接触している範囲がほとん ど補強板内であり, ピン孔内面の段差の影響が現れて いないためと考えられる. 暴風時載荷時の場合の曲げ モーメント分布も外力を等分布と仮定した場合の方が 近い. 
以上のことから，ピンの設計における外力の作用方 法としては，等分布荷重と仮定した場合の方が実測値 に近いと考えられる.

\section{5. 疲労試験}

\section{（1）試験計画}

疲労試験は暴風時を想定した載荷状態で実施した，疲 労試験荷重は, 上限 $980 \mathrm{kN}$, 荷重範囲としては $590 \mathrm{kN}$ とした.この荷重範囲の設定は, 先に述べた FEM 構 造解析結果から, 疲労試験の着目部である補強板外周 のすみ肉溶接の応力を参考とした. FEM 構造解析から 補強板外周の溶接部に生じる応力は, $1470 \mathrm{kN}$ 載荷時 で約 $160 \mathrm{MPa}$ である．この溶接部の 200 万回疲労強度 は, JSSC 疲労設計指針 ${ }^{4}$ による之荷重伝達型すみ肉溶

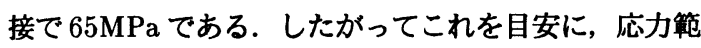
囲 70MPa に相当する荷重として, 荷重範囲を $590 \mathrm{kN}$, 下限荷重を $390 \mathrm{kN}$ とした.

ただし，本試験で設定した疲労試験の荷重範囲は，実 橋で予想される暴風時の繰り返し荷重（約 $200 \mathrm{kN}$ ) に 比べて大きい. したがって, この疲労試験の条件は, 実 橋で予想される荷重状態よりも過酷な状態となってい る. 本疲労試験では, ピン定着構造に繰り返し荷重が 作用した場合の疲労強度上の弱点部の検証と疲労挙動 の把握に重点を置いた.

疲労試験中のきれつ調查は, 綝り返し回数が約 30 万 回に一度の割合で主に目視で行い, 疲労きれつが発生 しやすいと思われる部分では磁㸮探傷試験 (MT) を併 用した.

疲労試験は繰り返し回数が 400 万回になるまで実施 し， 50 万回ごとに 5 万回のビーチマーク操作（下限荷 重を上げて荷重籍囲を $1 / 2$ にする）を行った.

試験中に検出されたきれつについては, 検出時のき れつの長さや位置などの発生状況を記録し, 以後適宜 にきれつの進展状況について調查した.

\section{(2) 破面㽢查}

疲労きれつの検出方法は主として目視によっている ため, 溶接のルート部などの内部から発生したきれつ が表面に現れたときには, きれつ発生からかなりの繰 り返しを受けている場合がある.このため, 疲労試験 中にビーチマーク操作を実施し, 試験終了後には破面 を露呈し, 疲労破面の観察を行い, きれつ発生の起点 や時期, および進展状況を調查した.

\section{(3) 疲労試験轺果}

疲労試験中に検出された疲労きれつは, 全 6 箇所で あり, 検出順にNo.1〜No.6 とした. これらきれつの検
出時の状況と進展状況のスケッチを図-13 に示す.

構造 I では, 繰り返し回数 105 万回時にきれつNo.1 およびNo.2を検出した. きれつの検出位置は, 補強板 下部溶接線のコーナー部のビード止端であった. これ らのきれつは補強板下部の溶接ビード止端に沿って進 展し, きれつNo.1 は溶接線のコーナー部から溶接止端 部を離れて定着板を水平方向に進展した. きれつの全 長は繰り返し回数 400 万回までに $200 \mathrm{~mm}$ を超える長 さにまで進展し, きれつNo.2 とともにきれつは, 補強 板下部の溶接部全長にわたった.

一方の構造 II では, きれつNo.3〜No.6 の 4 箇所で 検出した. きれつ検出時の回数は, きれつ No.3が 105 万回, No.4 6 は 150 万回であった. きれつの検出位 置は, きれつNo.3,4 が補強板の左右の斜め下方部の溶 接ビード止端, No.5,6 は No.3,4 の反対側の補強板の斜 め上の溶接ビード止端であった．これらのきれつは溶 接ビードの止端に沿って進展し, その後ビード止端か ら離れて定着板へと進展した。

疲労試験により, どちらの定着構造でも補強板の溶 接部が弱点となることが確認でき，構造 I, II ではき れつ検出時の繰り返し回数に差がないことから, 疲労 強度的にも差はないと考えられる。

また疲労きれつは, いずれの構造も溶接の定着板側 の止端部から発生し, ビードに沿って進展したのち定 着板に伸びた.

\section{（4）疲労きれつの発生, 進展挙動}

疲労試験中に検出した疲労きれつのうち，代表的な きれつNo.1 とNo.3 の破面を図-14 に示す.

きれつNo.1 の度労破面には若干の錆が見られ，ビー チマークの確認はできなかった. しかし, 錆の様子か ら判断して, きれつの起点は溶接線のコーナー部の溶 接ビード止端部と推定される.きれつNo.2 も同様な位 置を起点としていた. また，きれつNo.1については板 厚方向に深く進展し，定着板を貫通するほどにまで達 していた.

きれつNo.3は, 溶接ビードの止端部を起点としてお り，多数のきれつがうろこ状に重なり合って成長して いる. ビーチマークの観察より多数のうろこ状のきれ つは，ほぼ同じ時期に発生していることがわかった. ま た，このような破面の状況は，きれつNo.4〜6でも同 様であった，板厚方向のきれつ進展については，最大 で $20 \mathrm{~mm}$ 弱であり, 構造 I で生じたきれつNo.1 とほ ほ同程度の梁さであったが, 定着板の厚さが構造 I よ り厚いため, 板厚貫通までには至らなかった。

構造 I, II では板厚構成之補強板形状の違いから疲 労きれつの発生状況之進展挙動について違いが見られ た. 構造 I はきれつ発生部の溶接線の方向と力の作用 


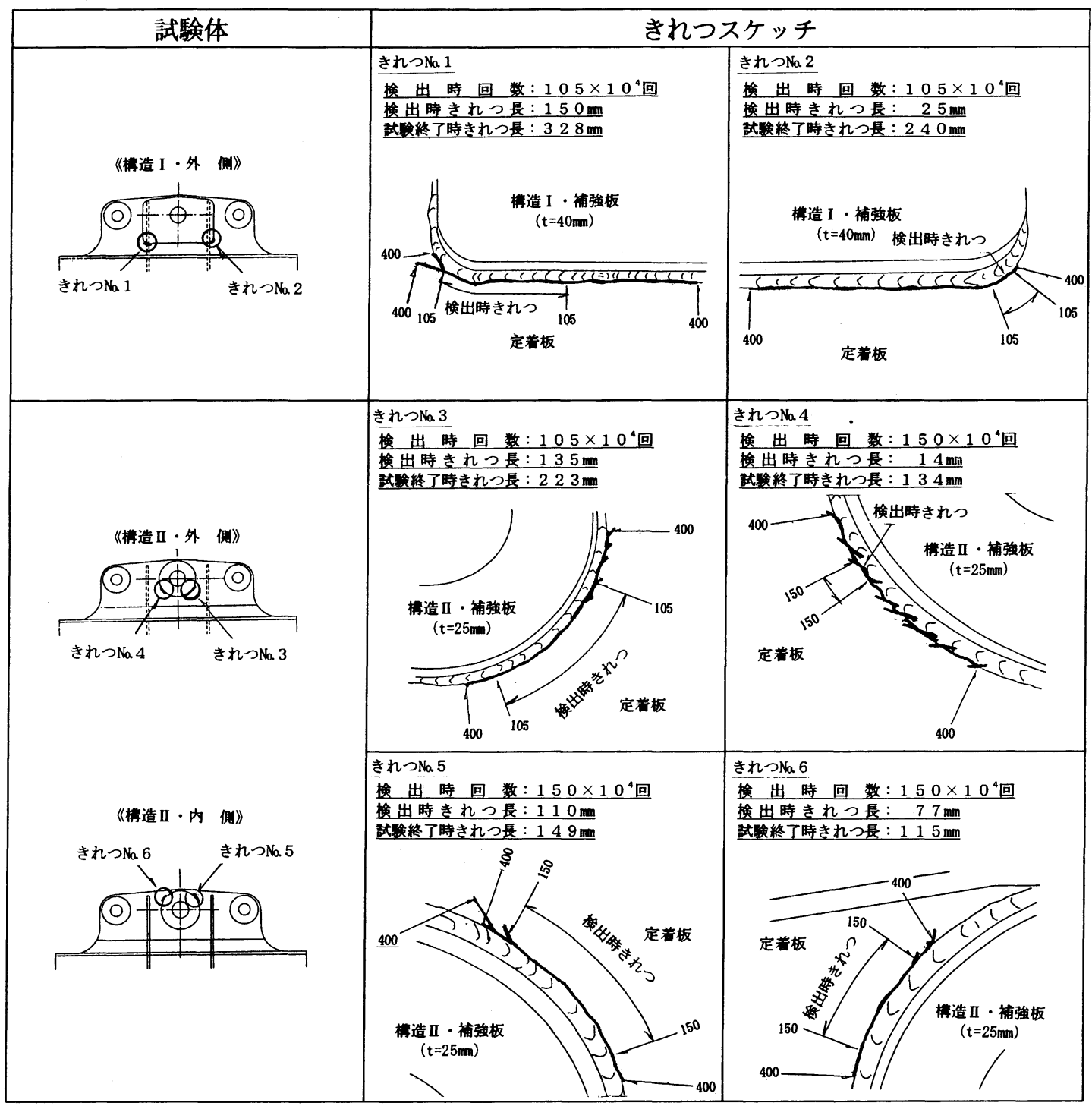

図-13 検出きれつのスケッチ

方向かほほほ直角になっているため, 補強板下部の溶接 線全長にわたってきれつは進展し, 定着板の板厚が薄 いこともあり, 板厚貫通直前にまで至った. 一方の補強 板が円形状の構造 II では, 溶接線の方向亡力の作用方 向の関係が位置によって異なるためか，きれつは多数 のうろこ状となって発生した．また，それらきれつは 溶接線をあまり沿うことなく定着板に進展したが, 定 着板の板厚が厚いことから進展は少なかった.

\section{6. まとめと考察}

\section{(1) ピンとピン孔の接触}

今回の補強板の溶接施工手順では, 補強板外周の溶 接による残留応力の影第により, 定着部ピン孔内面に 段差が生じる.これを防ぐためには，補強板の本溶接 後に再度のピン孔加工が必要である.

また，暴風時にはピンが傾斜し，完全に片当たりの 状態となるので, 補強板の設計には注意を払う必要が ある. 


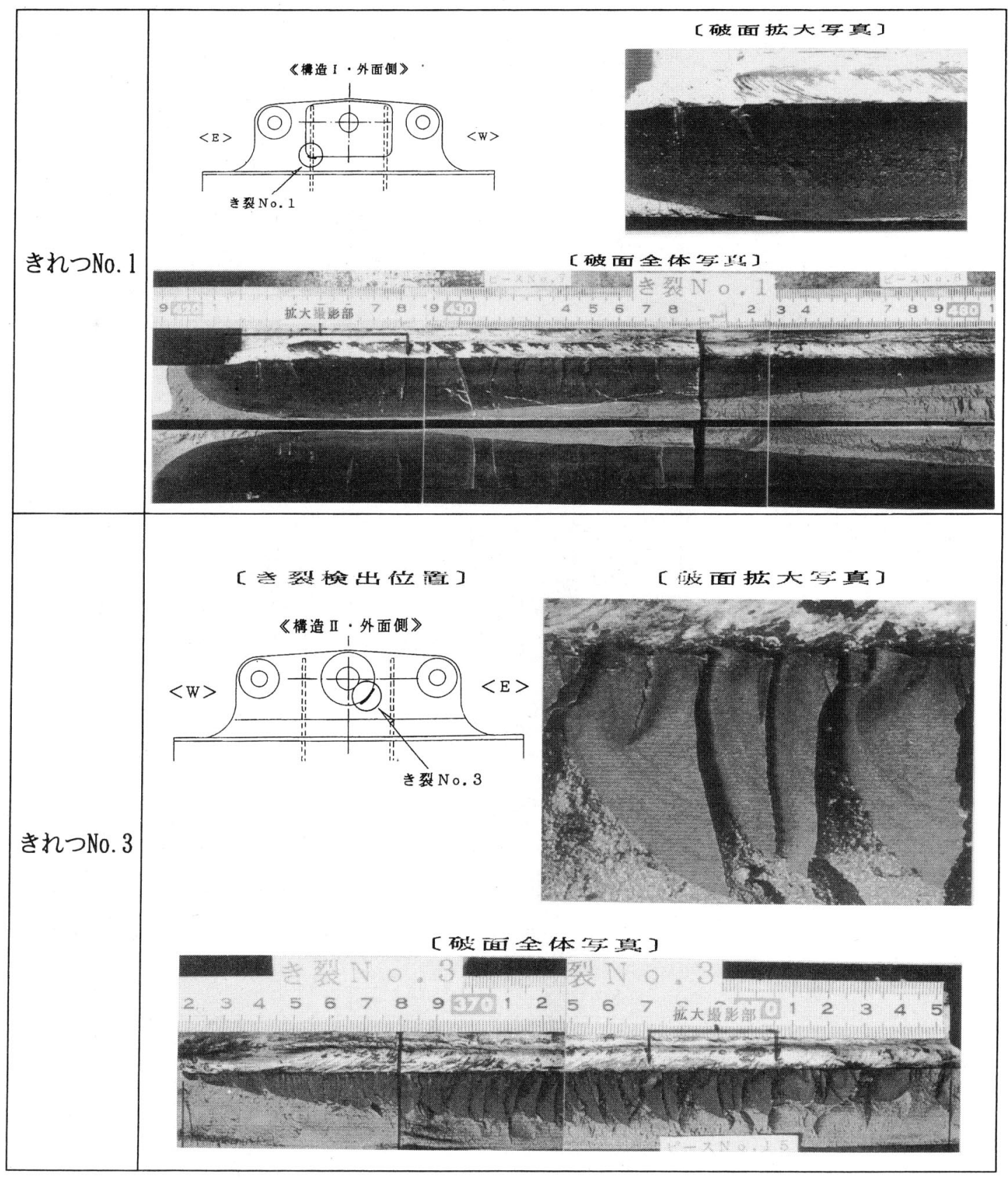

図-14 代表的きれつの疲労破面

（2）定着部とピンの応カ

ピンとピン孔の接触部では, 定着部材が降伏するよ うな高い応力が生じ, 特に暴風時ではピンが片当たり となり, 接触部で塑性変形が生じる.

ピンの応力分布は，作用する外力を集中荷重とした 場合より等分布と仮定した方が実際に近い。
定着部の応力は, 常時載荷時においてはどちらの構 造も特に問題となるような応力は発生しないが, 暴風 時載荷時では, 定着板に面外の力が作用し, 補強板外 周の溶接部に応力集中が生じる. 


\section{(3) 疲労式験結果}

疲労きれつは補強板外周の溶接部の定着板側止端部 から発生し, 溶接線に沿って成長した後, 定着板を進 展した. 定着板はピン定着構造の中では最も重要な部 材であるので，このような疲労きれつが発生し進展し た場合には，致命的な損傷になり得るため，疲労には 十分な注意が必要であると考える.

疲労強度的に構造 I とII ではきれつの発生時期に大 きな差はなく, 疲労強度的に同程度の度労強度と考え るが, 疲労きれつの発生状況と進展挙動については違 いが見られた。

\section{7. おわりに}

本試験で検討した 2 タイプのピンとピン孔の接触状 態の調查で, 暴風時ではピンが片当たりとなり, 常時
の状態においてもピン孔内面の凹凸のために均等に接 触しないことが明かとなった. そのためハンガーから の荷重は, 定着板と補強板には均等に分担して伝達さ れていない. したがって荷重の確実な伝達には, 定着 板と補強板を連結する溶接部のサイズや品質について 今後検討する必要がある.

\section{考支献}

1) 日本道路協会 : 道路橋示方专 - 同解説, 1994 年 2 月

2) H.Hertz : Über die berühbung fester elastischer Körper, J. für die reine u.angew. Mathem., 92(1881) 156.

3）日本道路協会：道路橋支承便卧，1991 年 7 月

4）日本銅構造協会：鉦構造物の疲労設計指針・同解説, 1993 年 4 月

(1995.5.30 受付)

\title{
FORCE TRANSMISSION MECHANISM AND FATIGUE BEHAVIOR OF A PIN-CONNECTION ANCHOR OF HANGER FOR A LONG-SPAN SUSPENSION BRIDGE
}

\author{
Harukazu OHASHI, Yuji FUJII, Shuichi ONO and Chitoshi MIKI
}

\begin{abstract}
At a pin connection detail of suspender ropes to chord member of stiffening truss for a suspension bridge, all loads are transmitted by bearing of pin and pin plate. Further at a wind condition, out-of-plane force acts repetitively at the connection due to the horizontal component of suspender rope tension caused by the relative movement between stiffening truss and main cables. This creates nonuniform bearing stress condition on pin connection. This report presents the results of static loading test and fatigue test on a full-scale specimen with two proposed pin connection detail a truss-stiffened long-span suspention bridge in order to verify the weak point and the fatigue strength.
\end{abstract}

